Terr. Atmos. Ocean. Sci., Vol. 18, No. 1, 117-128, March 2007

\title{
Conformity of MUSLE Estimates and Erosion Plot Data for Storm-Wise Sediment Yield Estimation
}

\author{
Seyed Hamidreza Sadeghi ${ }^{1,}{ }^{*}$, Takahisa Mizuyama ${ }^{2}$, and Babak Ghaderi Vangah ${ }^{3}$
}

(Manuscript received 23 August 2006, in final form 2 December 2006)

\begin{abstract}
In this study, the conformity of mathematical model of the MUSLE for the estimation of storm-wise sediment yield in plots was examined at Matash Ranch in northern Iran. For the measurement of sediment yield, three plots were established within each openly grazed and manually harvested area. The MUSLE model was applied through determining the entire required inputs for the study plots of $\mathbf{2 4}$ storm events, which occurred during the study period from May to September 2004. The quantity results were then statistically compared using paired t-Test analysis. The results of the study verified the disability of the model in sound prediction of sediment yield on storm basis for the study area. Additionally, a high level of agreement beyond $86 \%$ was found between estimated and measured sediment yield which created the possibility of comparative evaluation of the effects of different land use managerial approaches on sediment yield in the study area.
\end{abstract}

(Key words: Erosion plot, Soil erosion, Sediment yield, MUSLE, Watershed management, Iran)

\section{INTRODUCTION}

Soil erosion is one of the most significant forms of land degradation in Iran and is greatly influenced by land use and management (Sadeghi et al. 2004a). Evaluating the effects of manage-

\footnotetext{
${ }^{1}$ Department of Watershed Management Engineering, College of Natural Resources and Marine Sciences, Tarbiat Modares University, Iran

${ }^{2}$ Laboratory of Erosion Control, SABO, Graduate School of Agriculture, Kyoto University, Kyoto, Japan

${ }^{3}$ Department of Range Management Engineering, College of Natural Resources and Marine Sciences, Tarbiat Modares University, Iran

* Corresponding author address: Prof. Seyed Hamidreza Sadeghi, Department of Watershed Management Engineering, College of Natural Resources and Marine Sciences, Tarbiat Modares University, Iran; E-mail: sadeghi@modares.ac.ir
} 
rial approaches to soil erosion and sediment yield is an awesome task involving time consuming and cumbersome field measurements or utilizing faster albeit less accurate mathematical models. Mathematical models for soil erosion are based upon many concepts such as: empirical, causal or fundamental, stochastic and unit sediment graphs. The empirical models are simple, but do not penetrate the mechanisms of physical processes. In causal or fundamental models, the soil surface is subdivided into rills and inter-rill areas, while soil erosion is also analyzed in terms of physical sub-processes. Causal models require rainfall data, physiographic characteristics of basins, and field measurements to determine parameters (constants, exponents) for corresponding equations. This final requirement means these models cannot be applied to large basins. By contrast, empirical models require mostly rainfall data and maps (topographic, soil, vegetation, etc.). Unit sediment graphs, as well as unit hydrographs in the hydrology, are system functions describing the sediment behavior of basins. These enable the conversion of effective rainfall or detachment (system input) in the basin into sediment yield (system output). Generally, models based on system functions have the possibility to follow the time variation of sediment yield. By means of the stochastic models, sediment yield from a basin can be predicted as a function of rainfall or runoff; however, the sediment production mechanism in the basin is not taken into account. The stochastic models also require numerous data relating to runoff and sediment yield for the determination of parameters (Hrissanthou 2005).

The empirical models of USLE, MUSLE and their revised versions are widely used in hydrology and environmental engineering for computing the amount of potential soil erosion and sediment yield (Mishra et al. 2006). Since USLE (Wischmeier and Smith 1965) was developed for estimation of annual soil loss from small plots of an average length of $22 \mathrm{~m}$, its application to individual storm events and large areas leads to large errors (Hann et al. 1996; Kinnell 2005), but its accuracy increases if it is coupled with a hydrologic rainfall-excess model (Novotny and Olem 1994). One problem with the USLE model is that there is no direct consideration of runoff although erosion depends on sediment being discharged with flow, which varies with runoff and sediment concentration (Kinnell 2005). An improved erosivity factor was therefore introduced by Foster et al. (1977) to take into account the effect of runoff shear stress in terms of product of runoff volume and peak discharge on soil detachment for single storms. Williams (1975) and Williams and Berndt (1977) developed a modified version of the USLE (MUSLE) to derive a sediment yield estimation model based on runoff characteristics, as the best single indicator for sediment yield prediction (ASCE 1970; Williams 1975; Sadeghi et al. 2004b; Hrissanthou 2005), at the outlet of the watershed on storm basis and some affecting factors on soil erosion. Presently, only the MUSLE model is applied in storm-wise sediment yield prediction. This is due to a lack of adequate data regarding rainfall, channel geometry and hydraulics of entire stream systems which would otherwise be required. The MUSLE model optimizes hydrologic model parameters to estimate sediment yield. To formulate the hydrologic process of sediment yield, initially about 778 individual storm events in 18 catchments with areas ranging from 15 to 1500 hectares were investigated by Williams and Berndt (1977). The equation that best fit the data was of the following form with a correlation coefficient of $92 \%$ :

$$
\mathrm{S}=11.8\left(\mathrm{Q} \cdot \mathrm{q}_{\mathrm{p}}\right)^{0.56} \mathrm{~K} \cdot \mathrm{LS} \cdot \mathrm{C} \cdot \mathrm{P},
$$


where $S$ is sediment yield in tonnes, $Q$ is volume of runoff in $\mathrm{m}^{3}, \mathrm{q}_{\mathrm{p}}$ is peak flow rate in $\mathrm{m}^{3} \mathrm{~s}^{-1}$ and $\mathrm{K}, \mathrm{LS}, \mathrm{C}$, and $\mathrm{P}$ are respectively, the soil erodibility in t.h. $\mathrm{t}^{-1} \mathrm{~m}^{-1} \mathrm{~cm}^{-1}$, topography (dimensionless), crop management (dimensionless) and soil erosion control practice (dimensionless) factors similar to the USLE model (Williams and Berndt 1977).

Many researches have been conducted evaluating the MUSLE under different conditions around the world (Asokan 1981; Das 1982; Nicks et al. 1994; Banasik and Walling 1996; Kinnell and Riss 1998; Khajehee et al. 2001; Kinnell 2001; Rezaeifard et al. 2001; Erskine et al. 2002; Sadeghi 2004; Mishra et al. 2006). Some reports have been made in areas beyond which the MUSLE had initially been developed. The MUSLE has also been subjected to different modifications in some regions. Reviewing the literatures verifies the necessity of considering appropriate parameters for controlling sediment yield on storm basis. These are mostly different to those utilized for long term estimations and soil erosion. Nevertheless, application of the MUSLE for estimation of sediment yield based on plot size has not been documented precisely.

In the present study, an attempt has been made to assess the conformity of the MUSLE in estimation of storm-wise sediment yield for plots established within openly grazed and manually harvested areas at Matash Ranch, northern Iran.

\section{MATERIAL AND METHODS}

\subsection{Description of the Study Area}

The study sites were set up in a part of the Matash spring-fall mountainous rangeland in

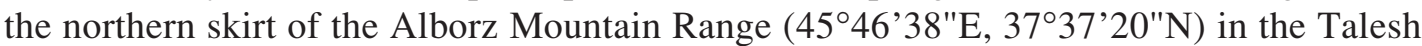
region as shown in Fig. 1. The watershed comprises 500 ha. The mean elevation and slope of the study are is $1800 \mathrm{~m}$ above mean sea level and $21 \%$, respectively. The general aspect of the watershed is also east-northeast. According to data collected since 1968 at a climatologic station in the vicinity of the study watershed, the general climate of the watershed is humid and cold. The area receives $1286.5 \mathrm{~mm}$ of annual precipitation. The maximum and the minimum temperatures are respectively reported as 30.0 and $-19.5^{\circ} \mathrm{C}$ with an average value of $8.5^{\circ} \mathrm{C}$. The area is covered by shill, limestone, sandstone, volcanic stones, tuff and conglomerate geologic formations over which shallow deep loamy sand soils exist (Ghaderi Vangah 2005).

In order to conduct our research, two sets of uniform plots were established within alfalfa cultivation and open grazing treatments (Fig. 1). Measurements of canopy cover and ground cover were conducted using $1 \mathrm{~m}^{2}$ plots and through random sampling. Soil texture was also determined based on samples taken form the top $20 \mathrm{~cm}$ of soil (Ghaderi Vangah 2005). A general description of the study sites has been given in Table 1 .

\subsection{Data Collection}

Three standard erosion plots of $22.17 \mathrm{~m}$ long by $1.83 \mathrm{~m}$ wide (Bennett 2001) were established in each study treatment with three replicates. Plots were properly isolated using wooden partitions of $20 \mathrm{~cm}$ in width. These were driven into the ground giving a partition height of $10 \mathrm{~cm}$ above the ground. Runoff and soil loss were measured by collection in 20-liter capacity buck- 


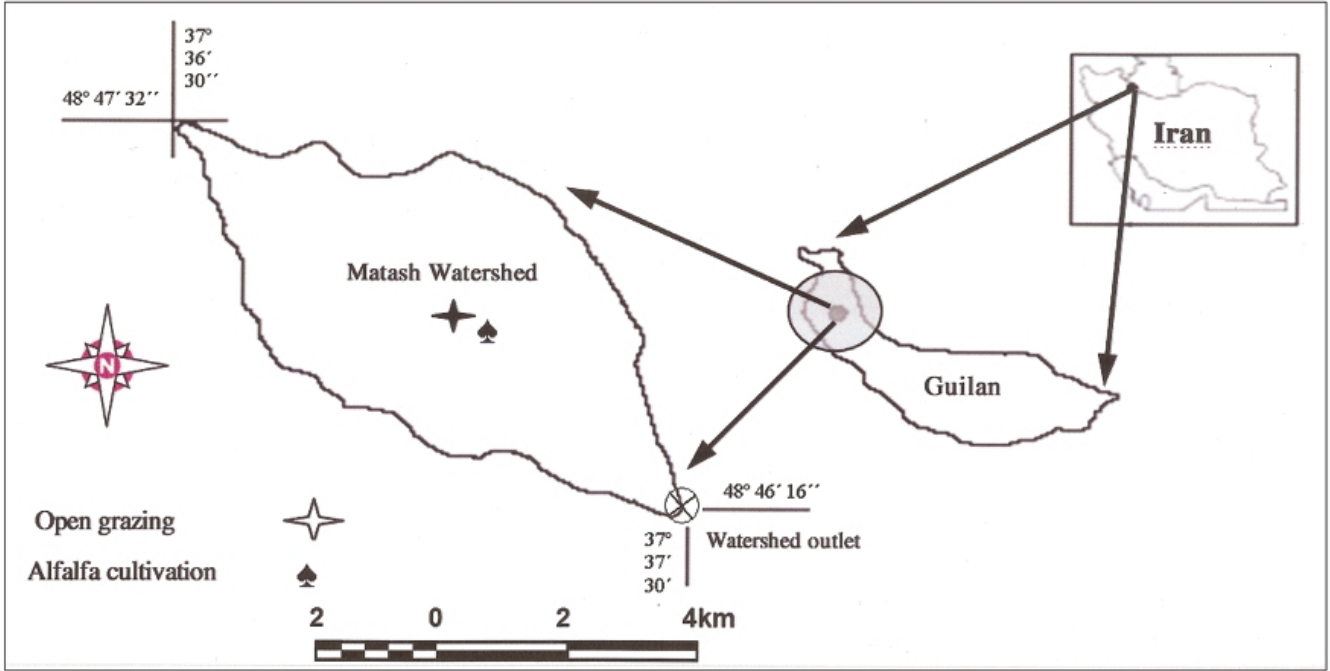

Fig. 1. Location of the study sites in study area, Iran.

Table 1. Vegetation and soil characteristics of open grazing and manually harvested treatments.

\begin{tabular}{c|c|c}
\hline Plot & Open grazing & Cultivated area \\
\hline Veriable & Trifolium-Pteridium & Medicago-Dactylis \\
Canopy cover (\%) & $72.00 \pm 5.06$ & $92.33 \pm 2.18$ \\
Stoniness (\%) & $6.84 \pm 3.27$ & $3.29 \pm 3.01$ \\
Bare Soil (\%) & $17.78 \pm 3.34$ & $6.25 \pm 1.52$ \\
Litter Cover (\%) & $3.83 \pm 0.61$ & $4.05 \pm 0.87$ \\
Organic Matter (\%) & $3.24 \pm 0.79$ & $4.62 \pm 0.34$ \\
Production (kg/ha) & $613.90 \pm 27.30$ & $1600.40 \pm 85.90$ \\
Range Condition & Moderate & Excellent \\
\hline
\end{tabular}


ets (Khan and Ong 1997), which were placed at the bottom of each runoff plot. The collection buckets were connected to the runoff plots via PVC tubes, which collected both soil sediments and runoff water from the full $22.17 \times 1.83 \mathrm{~m}$ plots after every rainfall event. Sediment concentration was determined through sampling collected runoff at the out let of each plot. Oneliter samples were then taken after mixing the entire runoff for lab analysis. Sediment content was determined by drying and weighing (Inbar and Lierena 2000). Sediment yield was assumed equal to the rate of soil erosion owing to the small size of the study plots. Runoff and sediment measurements were conducted for 24 natural storm events occurring during the study period from early May to late September 2004. Rainfall specifications were also collected from a manual raingauge on storm basis.

\subsection{Application of the MUSLE}

In the present study, storm-wise sediment yield was estimated using the MUSLE as given in Eq. (1) for the complete set of storm events occurring during the study period. Values for runoff volume were extracted from data collected during the study period. The parameter $\mathrm{q}_{\mathrm{p}}$ for the study plot was determined by the following formula based upon the SCS triangular hydrograph analysis procedure (Hrissanthou 2005):

$$
\mathrm{q}_{\mathrm{p}}=0.278 \mathrm{Ad} / \mathrm{T}_{\mathrm{p}}
$$

where $q_{p}$ is peak runoff rate $\left(\mathrm{m}^{3} \mathrm{~s}^{-1}\right)$, A is area $\left(\mathrm{km}^{2}\right)$, $d$ is runoff depth $(\mathrm{mm}), T_{p}$ is the rise time of the hydrograph (h) (time from the beginning of runoff to the time of peak runoff). The rise time, $T_{p}$, was calculated as a function of the time of concentration of the plot, which was also calculated through determining the surface runoff velocity by the classical Manning's formula (Satterlund and Adams 1992; Hann et al. 1996).

The soil erodibility factor $(\mathrm{K})$, as a function of soil texture and measure of the potential erodibility of soil, was determined with the help of soil characteristics for the study plots reported by Ghaderi Vangah (2005) and applying soil erodibility nomograph (Wischmeier and Smith 1965; Renard et al. 1991; Das 2000). The topography or slope length and steepness factor (LS), accounting for the overland runoff length and slope, was also calculated using the following formula for slopes $>4 \%$ (Mishra et al. 2006).

$$
\mathrm{LS}=\mathrm{L}^{0.5}\left(0.0138+0.00974 \mathrm{Y}+0.001138 \mathrm{Y}^{2}\right)
$$

where $\mathrm{Y}$ is the gradient (\%) over the runoff length and $\mathrm{L}$ is the length $(\mathrm{m})$ of slope from the point of origin of the overland flow to the point where the slope decreases to the extent that sedimentation begins (plot length). The cover management factor (C), estimates the effect of ground cover conditions, soil conditions, and general management practices on erosion rates. It generally reflects the degree of protection the soil surface has against the impact of rain drops and subsequent loss of soil particles, and was estimated using vegetation cover conditions in the study plots. The supporting conservation practice factor $(\mathrm{P})$, which accounts for the effectiveness of erosion control practices, such as land treatment by contouring, compacting, 
establishing sedimentation basins, and other control structures and includes treatments that retain eroded particles and prevent them from further transport, was assigned a value of 1 (Ponce 1989; Renard et al. 1991; Singh 1992; Novotny and Olem 1994; Hann et al. 1996; Laflen and Moldenhauer 2003), since no conservation measure applied in the study plots.

\subsection{Analysis Methodology}

The accuracy of estimated values obtained through application of the MUSLE was investigated using the determination coefficient, $\mathrm{R}^{2}$. All measured (plots) and estimated (MUSLE) sediment data within each study area on storm basis were subjected to dependent (Paired) sample t-Test. The entire statistical calculations were made using SPSS13.0 and Sigmaplot 9.0 statistical packages with $\mathrm{P}<0.01$ as the level of significance.

\section{RESULTS AND DISCUSSIONS}

All required information and data were either collected or determined for the application of the MUSLE at Matash Ranch in northern Iran. The watershed parameters and runoff data collected for 24 storm events occurred from May to September 2004 were used to apply the model given in Eq. (1). The soil erodibility was assumed 0.0312 (Hann et al. 1996) in both plot sets, since soil texture was identical (loamy sand). The crop management factor was assigned values of 0.1 and 0.01 (Renard et al. 1991; Hann et al. 1996) for openly grazed and cultivated plots, respectively. The soil erodibility and crop management factors were supposed constant for each plot sets since the period of the study was short and the effects of grazing and harvesting could be considered in runoff-related factors (Kinnell 2005). The soil conservation practices factor $(\mathrm{P})$ was also assumed 1 for both the treatments, since no control measure was implemented. The Manning's roughness coefficient was also respectively estimated as 0.13 and 0.24 for natural rangeland and cultivated plot (Hann et al. 1996). The entire dataset and the results of applying the MUSLE in the study area have been summarized in Table 2.

The result of the comparative evaluation between measured and estimated sediment yield data has also been depicted in Fig. 2. According to the results shown in Fig. 2, it is simply understood that the MUSLE has considerably under-estimated the sediment yield in the study plots by some thousands of times. However, it is seen in the Fig. 2 that the estimated points in cultivated treatment are less scattered compared to those belonging to the openly grazed treatment, which verifies the consistency and stability of the conditions governing the study plot. The significant difference between the measured sediment yield with mean values of 14 . 0713 and $2.7296 \mathrm{gr}$ and those estimated with mean values of 0.0221 and 0.000264 , respectively, associated with openly grazed and cultivated rangeland plots has also been proved by t-Test the results of which have been summarized in Table 3. The deviation criterion (Mitchell 1997) which is the prediction minus observation values were respectively found -14.049 and -2.729 as the averages for open and cultivated treatments. It along with the mean error of estimation beyond $-99.74 \%$ showed a big difference between each data set indicating the incompatibility of the MUSLE for the study's purpose. 
No logical closeness of data points to the prefect line indicates rejecting model performance for the estimation of sediment yield generated in the plots. The model did not give reasonable results, when compared with data from both study plots under natural rainfall. These results prove that the MUSLE does not produce reasonable estimates of sediment yield under the aforesaid conditions and therefore the procedure followed in this research can be used only to comparatively evaluate the effects of alternative management practices on soil erosion and sediment yield control as stated by Foster et al. (1981) in the application of developed soil erosion and sediment yield models in field-sized areas. The relationship between measured sediment yield and predicted soil loss using the MUSLE was highly significant at a

Table 2. Rainfall, runoff and sediment characteristics of study storm events along with estimated data of application of the MUSLE to Matash watershed, Iran.

\begin{tabular}{|c|c|c|c|c|c|c|c|c|c|c|c|c|}
\hline \multirow{3}{*}{ No. } & \multirow{3}{*}{ Date } & \multicolumn{3}{|c|}{ Rainfall Characteristics } & \multicolumn{4}{|c|}{ Runoff specifications } & \multicolumn{2}{|c|}{$\begin{array}{c}\text { Measured Sediment } \\
\text { (gr) }\end{array}$} & \multicolumn{2}{|c|}{$\begin{array}{c}\text { Estimated Sediment } \\
(\mathrm{gr})\end{array}$} \\
\hline & & \multirow[b]{2}{*}{$\begin{array}{l}\text { Depth } \\
(\mathrm{mm})\end{array}$} & \multirow[b]{2}{*}{$\begin{array}{l}\text { Duration } \\
\text { (h) }\end{array}$} & \multirow[b]{2}{*}{$\begin{array}{l}\text { Intensity } \\
(\mathrm{mm} / \mathrm{h})\end{array}$} & \multicolumn{2}{|c|}{ Open Grazing plot } & \multicolumn{2}{|c|}{ Cultivated plot } & \multirow[b]{2}{*}{ Open } & \multirow[b]{2}{*}{ Cultivated } & \multirow[b]{2}{*}{ Open } & \multirow[b]{2}{*}{ Cultivated } \\
\hline & & & & & $\begin{array}{l}\text { Volume } \\
\left(\mathrm{m}^{3}\right)\end{array}$ & $\begin{array}{c}\text { Peak } \\
10^{-4} \\
\left(\mathrm{~m}^{3} / \mathrm{s}\right)\end{array}$ & $\begin{array}{l}\text { Volume } \\
\left(\mathrm{m}^{3}\right)\end{array}$ & $\begin{array}{c}\text { Peak } \\
10^{-6} \\
\left(\mathrm{~m}^{3} / \mathrm{s}\right)\end{array}$ & & & & \\
\hline 1 & 2004.05 .05 & 3.31 & $00: 30$ & $6 / 62$ & 0.00180 & 0.09 & 0.00051 & 0.04 & 0.27 & 0.03 & 0.00536 & 0.00001 \\
\hline 2 & 2004.05 .10 & 6.94 & 03:00 & 2.31 & 0.00537 & 0.04 & 0.00089 & 0.10 & 2.80 & 0.09 & 0.00601 & 0.00003 \\
\hline 3 & 2004.05 .13 & 8.66 & 02:00 & 4.33 & 0.00676 & 0.05 & 0.00115 & 0.15 & 3.95 & 0.20 & 0.00846 & 0.00004 \\
\hline 4 & 2004.05 .13 & 9.93 & 03:25 & 2.90 & 0.00883 & 0.08 & 0.00190 & 0.35 & 7.14 & 0.50 & 0.01263 & 0.00009 \\
\hline 5 & 2004.05 .14 & 18.94 & $03: 40$ & 5.17 & 0.01919 & 0.30 & 0.00329 & 0.86 & 36.13 & 1.72 & 0.04028 & 0.00020 \\
\hline 6 & 2004.05 .15 & 4.55 & 02:00 & 2.27 & 0.00300 & 0.01 & 0.00044 & 0.03 & 1.04 & 0.04 & 0.00251 & 0.00001 \\
\hline 7 & 2004.05 .17 & 15.28 & 02:10 & 7.05 & 0.01823 & 0.28 & 0.00312 & 0.79 & 32.85 & 1.51 & 0.03732 & 0.00019 \\
\hline 8 & 2004.05 .23 & 12.29 & $02: 20$ & 5.26 & 0.01190 & 0.14 & 0.00215 & 0.43 & 11.80 & 0.56 & 0.01973 & 0.00011 \\
\hline 9 & 2004.05 .30 & 11.62 & $02: 10$ & 5.36 & 0.01237 & 0.15 & 0.00184 & 0.33 & 13.84 & 0.32 & 0.02088 & 0.00009 \\
\hline 10 & 2004.05 .31 & 5.79 & 01:20 & 4.34 & 0.00523 & 0.03 & 0.00052 & 0.04 & 3.24 & 0.04 & 0.00577 & 0.00001 \\
\hline 11 & 2004.06 .04 & 16.24 & 03:00 & 5.40 & 0.01452 & 0.19 & 0.00188 & 0.34 & 14.96 & 0.34 & 0.02655 & 0.00009 \\
\hline 12 & 2004.06 .12 & 20.20 & 03:30 & 5.77 & 0.01983 & 0.32 & 0.00173 & 0.30 & 37.14 & 0.40 & 0.04231 & 0.00008 \\
\hline 13 & 2004.06 .19 & 16.78 & $02: 30$ & 6.71 & 0.01516 & 0.20 & 0.00158 & 0.25 & 17.46 & 0.32 & 0.02833 & 0.00007 \\
\hline 14 & 2004.06 .29 & 11.05 & $02: 25$ & 4.57 & 0.01120 & 0.12 & 0.00704 & 3.08 & 10.32 & 7.66 & 0.01801 & 0.00064 \\
\hline 15 & 2004.07 .03 & 9.01 & 01:40 & 5.41 & 0.00896 & 0.09 & 0.00541 & 1.99 & 7.15 & 4.35 & 0.01291 & 0.00043 \\
\hline 16 & 2004.07 .12 & 10.85 & $02: 10$ & 5.00 & 0.01223 & 0.14 & 0.00551 & 2.04 & 14.77 & 3.93 & 0.02055 & 0.00044 \\
\hline 17 & 2004.07 .20 & 16.43 & $02: 15$ & 7.30 & 0.01838 & 0.28 & 0.00620 & 2.50 & 32.64 & 5.34 & 0.03777 & 0.00053 \\
\hline 18 & 2004.08 .04 & 18.15 & $02: 15$ & 8.06 & 0.01594 & 0.22 & 0.00388 & 1.14 & 14.42 & 2.31 & 0.03053 & 0.00026 \\
\hline 19 & 2004.08 .06 & 3.78 & $00: 50$ & 4.54 & 0.00202 & 0.01 & 0.00056 & 0.04 & 0.42 & 0.06 & 0.00139 & 0.00001 \\
\hline 20 & 2004.08 .13 & 21.65 & 03:40 & 5.90 & 0.01899 & 0.30 & 0.00187 & 0.34 & 22.39 & 0.40 & 0.03966 & 0.00009 \\
\hline 21 & 2004.09 .06 & 17.70 & 03:10 & 5.58 & 0.01520 & 0.21 & 0.00106 & 0.13 & 10.18 & 0.16 & 0.02844 & 0.00004 \\
\hline 22 & 2004.09 .12 & 16.30 & $02: 45$ & 5.92 & 0.01516 & 0.20 & 0.00907 & 4.70 & 12.56 & 12.38 & 0.02831 & 0.00093 \\
\hline 23 & 2004.09 .13 & 17.00 & $02: 15$ & 7.55 & 0.01819 & 0.28 & 0.01119 & 6.68 & 20.89 & 16.63 & 0.03720 & 0.00128 \\
\hline 24 & 2004.09 .17 & 13.21 & $02: 10$ & 6.09 & 0.01225 & 0.14 & 0.00724 & 3.23 & 9.35 & 6.22 & 0.02058 & 0.00067 \\
\hline
\end{tabular}



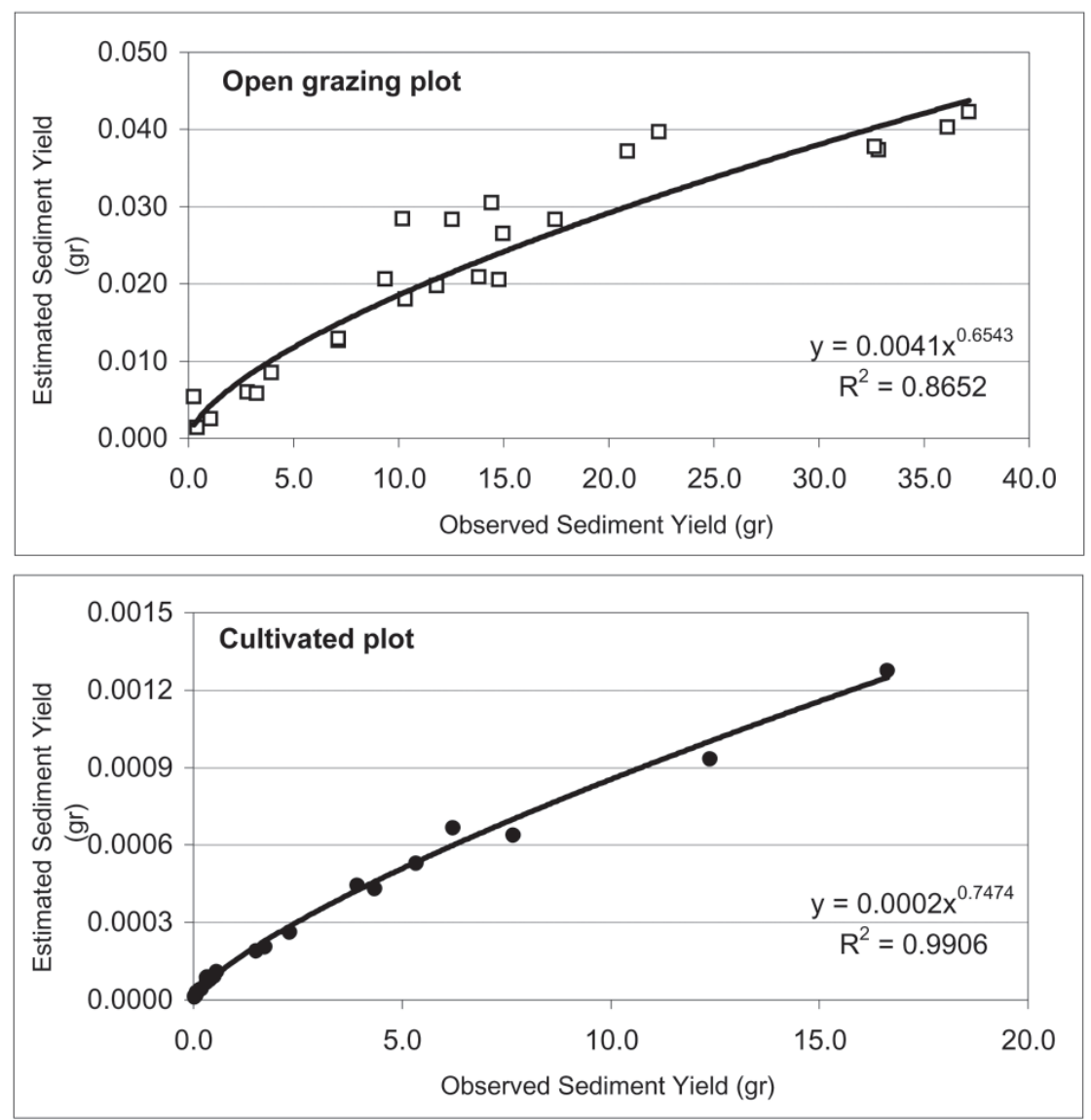

Fig. 2. Comparison between observed and computed sediment yield using MUSLE in open grazing (upper) and cultivated (lower) plots at Matash Ranch, Iran.

Table 3. Comparison of estimated and measured sediment yield in study plots in Matash Ranch, Iran.

\begin{tabular}{c|c|c|c|c}
\hline Variation & $\begin{array}{c}\text { Standard } \\
\text { Error }\end{array}$ & $\begin{array}{c}\text { Degree of } \\
\text { freedom }\end{array}$ & P-level & t-value \\
\hline Open grazing plot & 2.28940 & 23 & 0.00000 & 6.143 \\
Cultivated plot & 0.87551 & 23 & 0.00484 & 3.117 \\
\hline
\end{tabular}


level of less than $1 \%$ (Fig. 2). The high value of the determination coefficient beyond $86 \%$ revealed a reasonable relationship between estimated and measured sediment yield. This can be used for the purpose of the MUSLE calibration at a plot scale in the study area. This agrees with Erskine et al. (2002) who stated that land use effects on sediment yields and soil loss rates can be evaluated in small basins using the MUSLE. The results obtained during the present study oppose Asokan (1981), Das (1982), Khajehee et al. (2001), Rezaeifard et al. (2001), and Sadeghi (2004) who reported over-estimation of the MUSLE on a watershed scale. The deviation between the corresponding storm-wise values of measured and estimated sediment yield in the present study is generally attributed to the structure of the model which mainly focuses on sediment yield rather than soil erosion. Moreover, it is notable that sediment transport capacity by runoff is a key concept in the MUSLE model which may certainly play a more important role in delivering eroded sediment to the main outlets of the watersheds. The original development of the model for areas much larger than these plot sizes and not being governed by a humid climate (Williams and Berndt 1977) may also be supposed as reasons for justification of existing disagreement. Although the MUSLE model has not performed well in the case of sediment yield estimation for plot-sized areas, its application in watershed-sized areas is suggested owing to its simplicity and the accessibility of required inputs. This was also emphasized by Hrissanthou (2005) who developed sediment estimation models for watersheds without sediment data.

The above evaluation, however, excludes the direct effects of rainfall erosivity in the estimation of the eroded sediment in plots. It agrees with ASCE (1970), Williams (1975), Williams and Berndt (1977), Singh and Chen (1983), Sadeghi et al. (2004b), and Hrissanthou (2005) who stated, sediment yield from upland areas is generally better correlated with observed runoff than with rainfall. Therefore, it seems from the results of the present study that the application of rainfall-oriented soil erosion models in plot-sized experimental areas is preferred to runoff-based sediment yield models, although a longer and widespread record of sediment loading is needed to better define the natural condition and the response of sediment yield to human interference as emphasized by Kao and Liu (2001).

\section{CONCLUSION}

The application of the MUSLE model for plot-sized areas was examined for use on a storm-by-storm basis at the Matash Ranch in Iran. The results of the MUSLE application verified the disability of the model for sediment yield prediction in two rangeland plot-sized treatments. However, the calibrated version of the MUSLE model can be utilized for evaluation of the effects of different rangeland managerial approaches in the study area. Moreover, conducting similar studies in arid and semi-arid regions where the MUSLE model was originally developed is advised to facilitate drawing final conclusions. The extension of the present study to different plot sizes equipped with automatic climatologic and hydrometric recorders for determining the critical limit of the model's applicability is recommended. The establishment of long-term records of rainfall-runoff-sediment data is also needed for better sedimentyield-process modeling. Such models would lead to better water and soil conservation and watershed management. 
Acknowledgments The authors are very appreciative to Professor N. A. Safaeian for his valuable encouragements and helps. They also thank the Matsumae International Foundation (MIF), for a Post Doctoral Fellowship provided to the first author during which the present paper was materialized. The leave allowance given to the first author by the Tarbiat Modares University, Iran, to pursue his Post Doctoral Fellowship in Japan, is also thanked.

\section{REFERENCES}

ASCE (American Society of Civil Engineers), 1970: Sediment sources and sediment yields. J. Hydraul. Div., ASCE, 96, 1283-1329.

Asokan, K., 1981: Runoff and sediment yield from Bino subwatershed of Ramganga catchment. Master Thesis, G. B. Pant Univ. of Agr. and Tech., Pantnagar, India.

Banasik, K., and D. E. Walling, 1996: Predicting sedimentgraphs for a small agricultural catchment. Nord. Hydrol., 27, 275-294.

Bennett, H. H., 2001: Soil conservation. Agrobios, New Delhi, 993 pp.

Das, G., 1982: Runoff and sediment yield from upper Ramganga catchment. Ph. D. Thesis, G. B. Pant Univ. of Agr. and Tech., Pantnagar, India.

Das, G., 2000: Hydrology and soil conservation engineering. Asoke K. Ghosh, Prentic-Hall of India, $489 \mathrm{pp}$.

Erskine, W. D., A. Mahmoudzadeh, and C. Myers, 2002: Land use effects on sediment yields and soil loss rates in small basins of Triassic sandstone near Sydney, NSW, Australia. Catena, 49, 271-287.

Foster, G. R., L. D. Meyer, and C. A. Onstad, 1977: A runoff erosiovity factor and variable slope length exponents for soil loss estimates. Trans. Am. Soc. Agric. Eng., 20, 683687.

Foster, G. R., L. G. Lane, J. D. Dowlin, J. M. Laflen, and R. A. Young, 1981: Estimating erosion and sediment yield on field-sized areas. Trans. Am. Soc. Agric. Eng., 24, 12531262.

Ghaderi Vangah, B., 2005: Comparison of open grazing rangeland and planted areas in view point of runoff and sediment yield (Case study: Talesh, Matash summer Rangelands). Master Thesis, Range Management Engineering, College of Natural Resources and Marine Sciences, Tarbiat Modarres University, Iran, 104 pp.

Hann, C. T., B. J. Barfield, and J. C. Hayes, 1996: Design hydrology and sedimentology for small catchments. Academic Press Inc., San Diego, 487 pp.

Hrissanthou, V., 2005: Estimate of sediment yield in a basin without sediment data. Catena, 64, 333-347.

Inbar, M., and C. A. Lierena, 2000: Erosion processes in high mountain agricultural terraces in Peru. Mt. Res. Dev., 1, 72-79.

Kao, S., and K. K. Liu, 2001: Estimating the suspended sediment load by using the historical hydrometric record from the Lanyang-His watershed. Terr. Atmos. Ocean. Sci., 12, 401-414. 
Khajehee, A., A. Broshkeh, R. Sokouti, and M. Arabkhedri, 2001: Study on application of empirical model of MUSLE in Shahrchai watershed. Proceedings National Seminar on Land Management, Soil Erosion and Sustainable Development, Arak, Iran, 436-446.

Khan, A. A. H., and C. K. Ong, 1997: Design and calibration of tipping bucket system for field runoff and sediment quantification. Soil Water J., 52, 437-443.

Kinnell, P. I. A., 2001: The USLE-M and modeling erosion within catchments. In: Slott, D. E., R. H. Mohtar, and G. C. Steinardt (Eds.), 10th International Soil Conservation Organization Meeting, Purdue University and the USDA-ARS National Soil Erosion Research Laboratory, USA.

Kinnell, P. I. A., 2005: Why the universal soil loss equation and the revised version of it do not predict event erosion well? Hydrol. Process., 19, 851-854.

Kinnell, P. I. A., and L. M. Riss, 1998: USLE-M: Empirical modeling rainfall erosion through runoff and sediment concentration. Soil Soc. Am. J., 62, 1662-1672.

Laflen, J. M., and W. C. Moldenhauer, 2003: The USLE story. Special Publication No. 1, WASWC, $54 \mathrm{pp}$.

Mishra, S. K., J. V. Tyagi, V. P. Singh, and R. Singh, 2006: SCS-CN-based modeling of sediment yield. J. Hydrol., 324, 301-322.

Mitchell, P. L., 1997: Misuse of regression for empirical validation of models. Agric. Syst., 54, 313-326.

Nicks, A. D., R. D. Williams, J. R. Williams, and G. A. Gander, 1994. Estimating erosion with models having different technologies. Proc. 25th Annual Conf. Intl. Erosion Control Assoc., Reno, NV, 51-61.

Novotny, V., and H. Olem, 1994: Water quality: prevention, identification, and management of diffuse pollution. Wiley, New York, 1054 pp.

Ponce, V. M., 1989: Engineering hydrology: principles and practices. Prentice Hall, Englewood Cliffs, NJ, $640 \mathrm{pp}$.

Renard, K. G., G. R. Foster, G. A. Wessies, and J. P. Porter, 1991: Revised universal soil loss equation. J Soil Water Conserv., 46, 30-33.

Rezaeifard, M., A. R. Telvari, and M. Arabkhedri, 2001: Study on application of MUSLE in estimation of storm-wise sediments in Afjeh, Latian Basin. Proceedings National Seminar on Land Management, Soil Erosion and Sustainable Development, Arak, Iran 534542.

Sadeghi, S. H. R., 2004: Application of MUSLE in prediction of sediment yield in Iranian conditions. International Erosion Control Association, ISCO2004, Brisbane, Australia, 998, 1-4.

Sadeghi, S. H. R., D. A. Najafi, and M. Vafakhah, 2004a: Study on land use variation on soil erosion (Case study: Lenjan-e-Olya in Isfahan Province). Proceedings National Conference on Watershed Management and Water and Soil Resources, Kerman, Iran, 115123.

Sadeghi, S. H. R., J. K. Singh, and G. Das, 2004b: Efficacy of annual soil erosion models for storm-wise sediment prediction: a case study. Int. Agric. Eng. J., Thailand, 13, 1-14.

Satterlund, D. R., and P. W. Adams, 1992: Wildland Watershed Management, $2^{\text {nd }}$ Ed., John Wiley and Sons, 436 pp. 
Singh, V. P., 1992: Elementary Hydrology, Prentice Hall, Englewood Cliffs, 973 pp.

Singh, V. P., and V. J. Chen, 1983: The relationship between storm runoff and sediment yield, Technical Report 3, Water Resources Program, Department of Civil and Environmental Engineering, Louisiana State University, Baton Rouge, LA 70803.

Williams, J. R., 1975: Sediment-yield prediction with Universal Equation using runoff energy factor. Present and Prospective Technology for Predicting Sediment Yields and Sources, ARS-S-40, US Department of Agriculture, Agricultural Research Service, 244-252.

Williams, J. R., and H. D. Berndt, 1977: Sediment yield prediction based on watershed hydrology. Trans. Am. Soc. Agric. Eng., 20, 1100-1104.

Wischmeier, W. H., and D. D. Smith, 1965: Predicting rainfall-erosion losses from cropland east of the Rocky Mountains. Agriculture Handbook No. 282, Washington DC.

Sadeghi, S. H. R., T. Mizuyama, and B. Ghaderi Vangah, 2007: Conformity of MUSLE estimates and erosion plot data for storm-wise sediment yield estimation. Terr. Atmos. Ocean. Sci., 18, 117-128. 